\title{
Architecture and City Branding: Role of Iconic buildings
}

\author{
Rania El Messeidy \\ Lecturer, Department of Architecture, Faculty of Engineering, October University for \\ Modern Sciences and Arts (MSA) University, $6^{\text {th }}$ of October, Cairo, Egypt \\ rhamdi@msa.eun.eg rania h2000@yahoo.com
}

\begin{abstract}
City branding represents an interesting topic to researchers and policy makers. As of late, cities of developing nations have picked to utilize city branding as a strategy to help them compete economically with other cities in global. City branding use architecture especially beside other ways to make cities more visible, competitive and relevant to global world. According to various literature; iconic buildings are a basic tool of city branding. Using icons or symbols by architecture is old as the civilization began. Iconic or signature buildings have an important role as magnets; they can attract investments and tourists. Such structures reflect their cities identity and represent our understanding and thinking about these cities.

As of late, iconic buildings have increased expanding prevalence among approach policymakers and city designers. The premise of this development can be found in fruitful cases of iconic buildings that made cities vital after having a critical bad image. This paper aims to study city branding in terms of architecture and especially iconic buildings. The research highlights the definitions of brand, branding and city branding in relevance to architecture. It also highlights the importance of using iconic buildings as a tool for branding the city. In this sense, the research analyses two successful examples; Burj Khalifa in U.A.E and Bibliotheca Alexandrina in Egypt. The paper concludes that iconic buildings could express the identities of countries and help them to compete globally.
\end{abstract}

Keywords: Brands, Branding, City Branding, Branding Strategies, Iconic33 Buildings.

\section{Introduction}

Quick modern change has implied that a large number of countries can never again ensure that the conventional industrial products left could be an economical wellspring futuristic development. In the so-called knowledge, economy is the capacity to draw in and hold skilled and innovative work, to give intuitive milieus where new thoughts can develop, and so on (1). As of late, cities of developing nations have picked to utilize city branding as a strategy to help them compete economically with other cities in global. 
But are all places are similar? In other words can all cities follow the same strategy to be branded? Always people tie emotionally with places whether they just visited these places, work in it or even lived there. In this way, it is important to consider this dimension when branding a place. In planning process, bonding to a place is as critical to have attention. Thus cities need to focus on customer needs, draw its strategies and have much imagination providing a brand that help increase positivity, respect and loyalty. In general places are not homogenous. As consequence, it is not necessary that a brand strategy success in different places, as it is unique as the place is. It is the challenge now for many places to take control of their neglected identity and reputation for a long time.

It is important that cities leaders understand the reputation which make it attractive enough for visiting, living, investment and studying. Cities now are in a need to rethink about what they have of values, what they can offer in future. Also think about its strengths and then create, develop and demonstrate their values using appropriate on-brand actions (2).

One of the main strategies of branding a city is to build iconic buildings. This paper aims to study city branding in term of architecture and especially iconic buildings. The research highlights the definitions of brand, branding and city branding in relevance to architecture. It also highlights the importance of using iconic buildings as a tool for branding the city. In this sense, the research analyses two successful examples; Burj Khalifa in U.A.E and Bibliotheca Alexandrina in Egypt. The paper concludes that iconic buildings could express the identities of countries and help them to compete globally.

\section{Brand and Branding}

A brand is placed when enough people are seeing and thinking about the character of the brand (3). Brands and marking are not new. For Greek and Roman purposes, the mark was used as a distinctive guide or registered trademark of shops and brands of skilled workers (4).

The historical background of the "brand" is derived from the old word "Scandinavian" "brandr", which should burn. It refers to the registered trademark of animals and the identification of a person's property (5).

How are "brands" and "branding" characterized these days? As indicated by (6) brands are utilized to isolate items and administrations from different ones accessible in the market. Distinctive artistic sources have defined brands in different ways. Brands could be represented by logos, conspicuous organization names and pictures, character and worth frameworks, hazard reducers, developing elements, pictures in customers' psyches, characters and connections. Branding is a vital procedure to repute a company. It comprises of structuring, arranging and conveying the brand's name and character. Branding is an always adjusted procedure that incorporates promoting and conveying an incentive to consumers (7). 


\section{Place and City Branding}

Place branding is about linking the place image with the "true identity of place". (8; 9) have characterized place branding as "the planning technique of a place to fulfill the requirements of objective markets". (10) Indicated that geographic locations could act as items and services, and as well could be branded, and this will attract people and help in growing tourism and business (11).

City branding is an important part of a holistic strategy of planning, which aims to promote the city and make it more attractive to investors. This way to deal with comprehension and branding a city as a "product" (12).

Place branding incorporates a few unique patterns and types of branding: country branding, goal branding, culture and excitement branding.

Place branding is a mix of strategies that empowers a place to expand on its current qualities, revealed its identity and develop it for the future. These strategies are adjusted from commercial branding and leadership and organization improvement practices. Effective place branding guarantees that the place gets value from the acknowledgment of known qualities and positive activities (13). One of the fundamental characteristics of city branding is the utilization of "culture" as a basic apparatus to improve what cities need to compete and require on the urban image level.

The creation of recreational and social exercises, for example in historic centers, exhibitions and theaters, including celebrations and an entertaining state of purchase, means that a "social urbanism" architecture is an essential tool for creation, a marketable city image (14).

(15) Indicated that iconic architecture is an essential tool of city branding. City's image works on covering different partnership. This implies the responsibility of different actors. They also recommended that it is conceivable to receive a marketing philosophy for the administration of urban communities and to utilize apparatuses and standards of corporate marketing (7).

Applying basic branding principles to cities through marketing methods is simply not enough. Marketing cannot be used as an alternative to a theoretical inquiry grounded in architecture and urban design, when it comes to urban branding, especially since the origins of this practice are founded on the principles of monumental and architectural propaganda (16).

A study in the Nordic countries proposed three essential strategic areas in which the actors are trying to bring about change to create new city images and new brands. The first categories was brand building, events and emblematic projects; 2) brand strategy through planning strategies; 3) Brand through advertising. Very often, categories are used as contiguous processes in term of integration (1).

In her book titled "City Branding: Theory and Cases" Andrea Insch pointed out that, despite their differences, the urban branding activities carried out by some cities can 
identify a number of common problems, the most important of them are: definition of obstacles facing city brands and clarification of identity and image (2).

As mentioned before; although city branding could be achieved through various strategies, this study is limited on the role of iconic buildings in city branding.

\section{Iconic Buildings as a tool of City Branding}

Due to the social fracture and pluralism related with entrepreneur industrialism, numerous cities have turned to "reputed" architects to design iconic buildings that go beyond cultural, traditional and local differences.

Architecture has been utilized as an icon or image since the beginning of civilization (17). In Egypt, the pyramids were utilized as a method for showing their owners' power. The Parthenon in Athens and the Coliseum in Rome are examples of iconic architectural structures. In the middle Ages, cathedrals were significant for their monumentality and carried new urban structures to urban areas. Historians likewise report that modelers had a noticeable spot in the political existence of public administrators, both for giving extraordinary visibility through grand works and for their reputation, as exemplified by the situating of architects on the Pharaoh's righthand side at occasions and gatherings (18).This political significance - from rulers in classical times to presidents presently additionally means a feeling of the requirement for iconic buildings intended to stylishly attest governments, with the huge increment in cities and the globalization procedure, cities are becoming more able to lose their identity.

City branding tries to turn "urban icons" into components that uncover (or make) a local personality to facilitate this procedure and support social and historical uniqueness. These symbols can be of huge scale, including the "visual accidents" announced by (19), or of a littler scale (landmarks, tourist spots, perspectives, among others) with a particular trademark.

These elements, as indicated by (20), may enhance some of the strengths of the site, or may not be discernible, and contribute to visual disintegration that prevents that the physical image and mental environment be unified and percept.

Along these lines, as per (19), intelligibility is upgraded when visual and practical components are improved thinking about two key attributes: complexity and advancement.

On the other side $(19 ; 21)$ indicate that although innovation is very important issue in city marketing strategies, it should be noted that architecture does not currently take into account social characteristics but focuses on the search for a global aesthetic. This is the case today in Dubai.

Architecture empowers city branding through associating with a great cultural heritage which attributes a symbolic value, in addition to functional value (22).

Cities worldwide are not identical but unique. Each city has her own identity, influenced by her people, and other social and cultural factors. In this sense iconic 
architecture should respect all these factors, context should be considered and this in order to sustain the city's image and identity.

More recently, iconic buildings have become increasingly popular among city developers. The basis of this development is a very successful example of remarkable buildings that have revived a city with a problem of image: the Frank Gehry Museum in Guggenheim in Bilbao.

Investing in the development of the museum was an extraordinary achievement, transforming the image of a demolished modern city of Bilbao into a perceived universal community for culture and expressions of the human experience. Which drives numerous administrations, districts and civil decision-makers to truly consider making their own "Bilbao effect" (1).

Ignoring local culture before the appeal of "global images" will end up creating images of the city itself, which in the end will not reflect any local culture. This in turn will negatively affect long-term cities, because they can lose their authenticity, which is crucial to make the city' brand success. City governors should know the characteristics and values of their city. Otherwise, the images cities will lose the attraction of visitors (23).

\section{Case Studies}

As mentioned before; although city branding could be achieved through various strategies, this study is limited on the role of iconic buildings in city branding. The following case studies represent a successful examples of iconic buildings in Dubai, Alexandria and a promising iconic tower in the new administrative capital in Egypt.

\subsection{Burj Khalifa, Dubai, U.A.E}

\section{A. Project Background}

The Burj Khalifa, has a total height of $829.8 \mathrm{~km}$ and a surface (without antenna) of $828 \mathrm{~m}$ (24). The structure broke various tallness records.

The beginning of the Burj Khalifa was in 2004, and it completed totally with the exterior later in 2009, and the opening was in 2010. The idea of building the tower is based on a governmental decision. The government decided to diverse from the oilbased economy and to increase global acknowledgment.

Figure 1. Shows the height of Burj Khalifa compared to different well-known tall buildings. Ref. (25) 


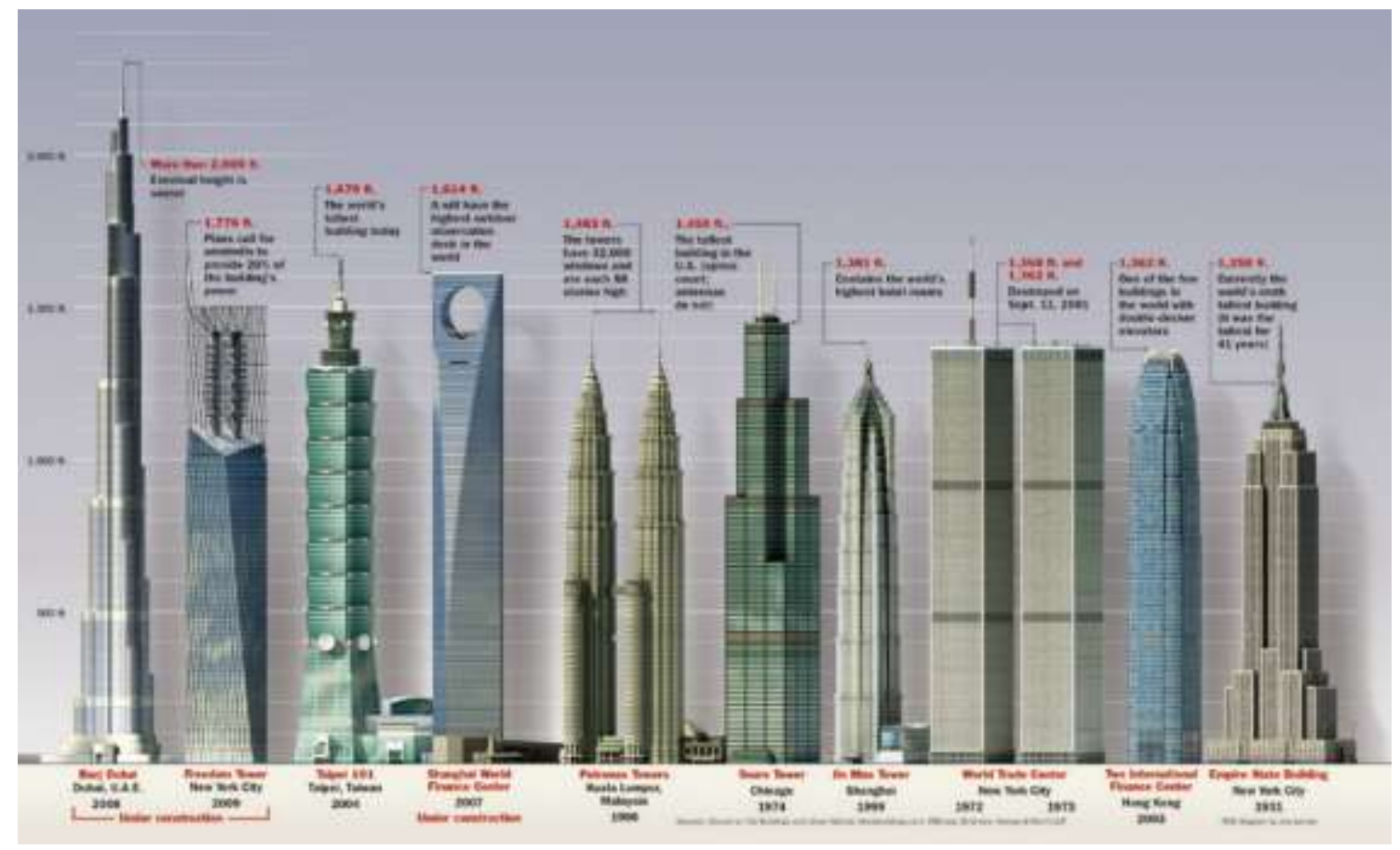

\section{B. Project Description}

Burj Khalifa is designed by Adrian Smith, of Skidmore, Owings and Merrill LLP (SOM). The structure is motivated by the Islamic engineering of the region. It has a Y-shape floor so as to upgrade private and inn space. Burj Khalifa has 57 lifts and 8 elevators. A focal center and wings are utilized to help its tallness (26). The tower has 27 setbacks forming a spiral pattern which decrease gradually as going upward to create outdoor terraces. The setbacks have a role in minimizing the vibration wind loading (27). The Burj is covered with more than 26,000 reflective glass panels and a textured stainless steel spandrel with a vertical tube (28). Architectural glass offers solar and thermal performance and glare protection in extreme sun, extreme temperatures and winds. The glass has an area of more than $174000 \mathrm{~m} 2$. The typical Burj curtain wall panels are 4' 6 "wide and 10' 8 " high, each weighing approximately 800 pounds. Larger panels are located near the edges of the building and higher panels near the top.

\subsection{Bibliotheca Alexandrina, Alexandria, Egypt}

\section{A. Project Background}

The Bibliotheca Alexandrina is a national library and cultural center on the mediterranean located in the Egyptian city of Alexandria.

Figure 2. Bibliotheca Alexandrina, Alexandria, Egypt. Ref. (29) 


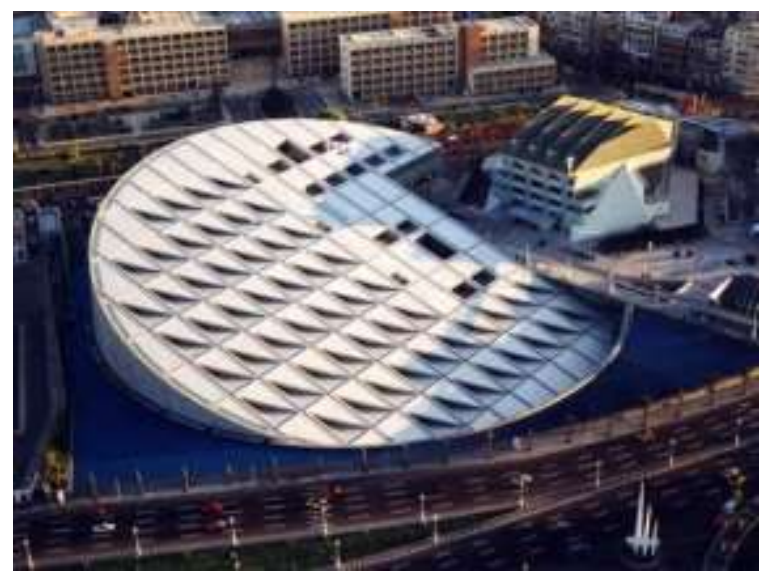

Figure 3. The Aswan granite wall. Figure (3). Mediterranean side of library. Ref. (30)

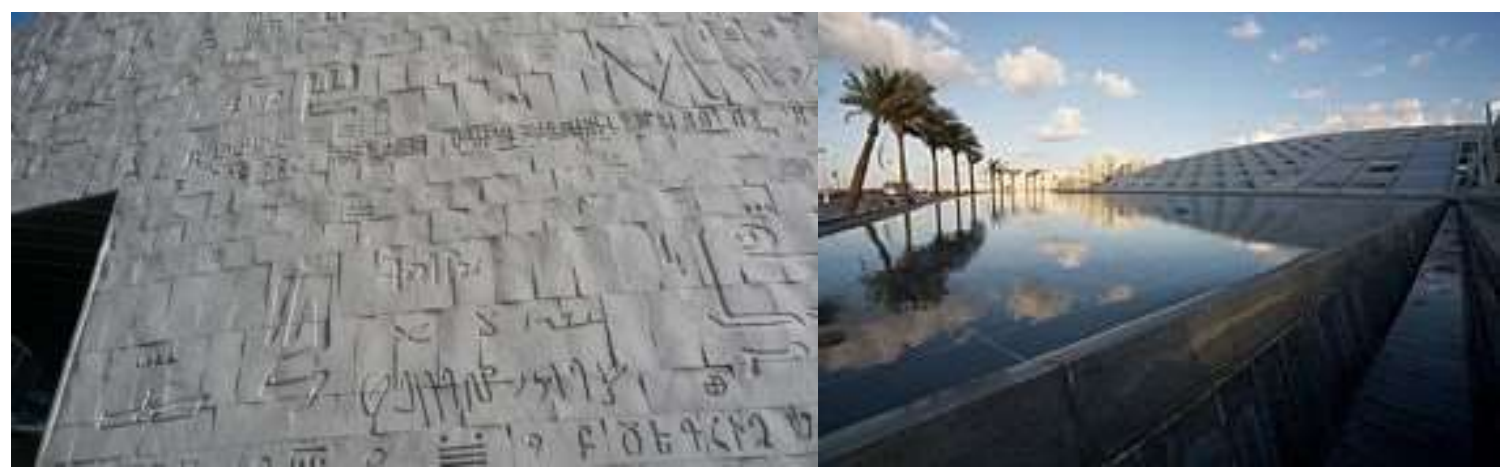

Figure 4. Interior shot for reading hall. Ref. (30)

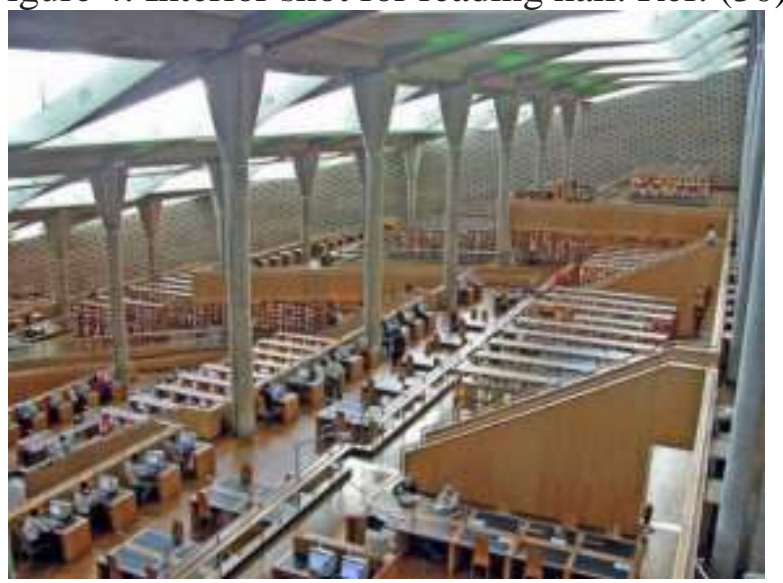

Reviving the old library goes back to 1974, when a committee shaped by the University of Alexandria picked a site for the new library situated between the campus and the coastline, close to the antiquated library. The restoration of the old library was not only supported by other people and authorities, but also supported by Egyptian politicians. UNESCO quickly resumed the idea of providing the Mediterranean with a center of cultural and scientific excellence. UNESCO organized an architectural competition in 1988 to choose a project worthy of the site 
and its heritage. The Norwegian architectural firm Snohetta won the competition with more than 1,400 applications.

\section{B. Project Description}

The library has a large dimensions, the shelf space contains eight million books. The main reading hall covers 20,000 square meters on eleven levels, beneath a 32-meterhigh glass paneled roof inclined towards the sea and had a diameter of $160 \mathrm{~m}$. The walls are gray granite of Aswan and decorated with characters of 120 different writings. It is a complex of special libraries, 4 museums, 15 permanent exhibitions, a planetarium, and a manuscript restoration lab (31).

\section{City Branding in Egypt Today}

The new administrative capital in Egypt is witnessing the construction of the tallest tower in Africa. It is the tallest tower in Egypt and Africa, with a height of 390 meters, will be built in the financial and business district of the new administrative capital.

Egypt is taking steps to complete its new administrative capital and to make it a global city with the most important buildings in Africa and the Middle East, hoping that the capital of the future will become a tourist shrine like Cairo, the old capital. The opening of the largest cathedral in the Middle East and the second largest mosque in the world in the administrative capital, about $45 \mathrm{~km}$ from the current capital, Egypt began to build the tallest tower in Africa in the central business district of the new capital.

When completed, the iconic tower will pull out of the Carlton Center Tower in central Johannesburg, currently the tallest tower in Africa at 222.5 meters, while iconic tower height is about 385 meters (32).

The iconic tower is not the only tower in the administrative capital as it is intended that administrative capital will be a hallmark of modern Egypt, just as the great pyramids and the sphinx were a sign of ancient Egypt.

The iconic tower has a 50-storey hotel for administrative use, apartments, villas, swimming pools, spas, children's playgrounds, 20 restaurants and show platforms, gold and fashion markets, leather products, computers, cinemas, theaters and an airstrip (33).

\section{Conclusions}

Branding is about uniqueness, differentiation from others; on this ground it is critical to be special and abstain from replicating what others are. An initial move towards this is to recognize local strengths and attributes. The flexibility in thinking about branding could transform the local weaknesses into strengths. City branding could be achieved using different strategies and the right decision should be based on the local characteristics and resources. City branding should reflect the local 
environment and let people get involved. The relationship between iconic architecture and city branding is old as the beginning of civilization. Iconic buildings have a role in city branding process; according to case studies, Burj Khalifa in Dubai, represented a governmental decision to diverse from the oil-based economy and to increase global acknowledgment. In Egypt, the idea of bibliotheca Alexandrina which aimed to revive the old library of Alexandria and restored its cultural role as a beacon of science. Today Egypt is also using the iconic building by constructing the tallest tower in Africa and the Middle East, hoping that the capital of the future will become a tourist shrine like Cairo, the old capital.

\section{Recommendations}

1. Cities should think wider, they need to discover their situation inside the Regional/National/Global.

2. It is important that each city has an organizational chart - Cities could hold a series of meetings where different actors could sit down and define their ideas to achieve a clear goal, a clear direction, a strategy and a good flow of internal / external communication.

\section{References}

1. Jansson, J., et al., (2006). "Image of the City: Urban Branding as Constructed Capabilities in Nordic City Regions". Department of Social and Economic Geography, Uppsala University, Nordic Innovation Centre. Stensberggata 25, NO-0170 Oslo, Norway.

2. Dinnie, k., (2011) “City Branding: Theory and cases”. ISBN 978-0-23024185-5, Palgrave Macmilan, UK.

3. Moilanen, T. \& Rainisto, S. (2009). "How to brand nations, cities and destinations. A planning book for place branding”. Palgrave Macmillan. Hampshire.

4. Riezebos, R. (2003). “Brand Management”. Pearson Education Limited. Harlow.

5. Lindberg-Repo, K, et al., (2009). “Titans of marketing”. Gummerus Printing Ltd. Jyväskylä.

6. Grönroos, C. (2009). Palvelujen johtaminen ja markkinointi. 3. painos. WSOYpro. Hel-sinki.

7. Jarvisalo, S., (2012). "How to build successful city brands? -Case Munich, Berlin \& Hamburg” Thesis Degree of Hotel and Restaurant Management, HAAGA-HELIA, University of Applied Sciences.

8. El Hakeh, A., (2018). "Between Branding and Identity, Re-imaging Historic Cairo”. Technische University Darmstadt. 
9. Kotler P, et al., (1999). "Marketing Places Europe: Attracting Investments, Industries, Residents and Visitors to European Cities, Communities, Regions and Nations". London, Pearson Education Ltd.

10. Keller, k., (2005). "Strategic Brand Management: Building, Measuring and Managing Brand Equity”. 2nd Edition, Pearson Prentice Hall.

11. Mishra, A., (2016). "Destination Branding: A Case Study of Hong Kong”, the IUP Journal of Brand Management, Vol. VII, No. 3, 2010.

12. Ashworth, G. J. and Voogd, H. (1990). "Selling the City”. London: Belhaven Press.

13. Kavaratzis, M., (2007). "Cities and their brands: Lessons from corporate branding”. Place Branding and Public Diplomacy Vol. 5, 1, 26-37 www.palgrave-journals.com/pb/

14. Wong, M., (2007). "Urban Systems Studies. A City of Culture: Planning for the Arts”. Centre for Liveable Cities. ISBN 978-981-11-5127-9. Singapore.

15. Kavaratzis, M. \& Ashworth, G. (2005). "City branding: an effective assertion of identity or a transitory marketing trick?" Retrieved from http://bestplaceinstytut.org/www/wp-content/uploads/2010/09/KavaratzisAshworth-2005-TESG.

16. Muratovski, G., (2012). "Urban Branding: The Politics of Architecture". Design Principles and Practices: An International Journal - Annual Review, Volume 6, 2013, www.designprinciplesandpractices.com, ISSN 18331874DOI: 10.18848/1833-1874/CGP/v06/38311.

17. 5 Strongest Historical Architecture Influences to Architecture. Retrieved from https://beebreeders.com/5-strongest-historical-architecture-influencesto-architecture

18. Leslie Sklair., (2006) Iconic architecture and capitalist globalization, City, 10:1, 21-47, DOI: 10.1080/13604810600594613

19. Castillo-Villar, Fernando R., (2016). Urban icons and city branding development. Journal of Place Management and Development 9(3):255-268, DOI: 10.1108/JPMD-03-2016-0013

20. Lynch, K. (1960). "The Image of the City”. Massachusetts: The MIT Press.

21. G Brizotti-Pasquotto, L Medrano. (2014). "Iconic Buildings and City Marketing. The Central area of Sao Paulo". Revista Bitacora Urbano Territorial, 24 (2).

22. Kavaratzis, M. (2005). "Branding the City through Culture and Entertainment”. The AESOP 2005 Conference, Vienna, 13-18.

23. Riza, M., (2015). "Culture and City Branding: Mega Events and Iconic Buildings as Fragile Means to Brand the City”. Open Journal of Social Sciences, 2015, 3, 269-274. 
24. Bianchi, S., Critchlow, A. (2010). "World's Tallest Skyscraper Opens in Dubai". The Wall Street Journal. Retrieved from https://www.wsj.com/articles/SB10001424052748703580904574638111667 $\underline{658806}$

25. Rmmojado., (2011). Tallest Buildings in the World. Retrieved from https://visual.ly/community/infographic/economy/tallest-buildings-world

26. Belleza, I., (2010). "Burj Khalifa: Towering challenge for builders". Retrieved from https://gulfnews.com/business/property/burj-khalifatowering-challenge-for-builders- 1.561802

27. William F. Baker., James J. Pawlikowski, S.E., (2012). "Higher and Higher: The Evolution of the Buttressed Core". Retrieved from https://academic.csuohio.edu/duffy s/CVE_601_Struct_1.pdf

28. Saberi, M., (2008). "Burj Dubai is the height of success". Retrieved from https://web.archive.org/web/20100107060153/http://gulfnews.com/news/gulf /uae/housing-property/burj-dubai-is-the-height-of-success-1.55605

29. Tawfeek, F., (2017). Bibliotheca Alexandrina to rebuild 'Egypt's memory'. Retrieved from https://egyptindependent.com/bibliotheca-alexandrinarebuild-egypts-memory/

30. Zakzouk, S., (2017). Past and Present: The Bibliotheca Alexandrina. Retrieved from https://theculturetrip.com/africa/egypt/articles/past-andpresent-the-bibliotheca-alexandrina/

31. "Bibliotheca Alexandrina - Lonely Planet" (2016). Retrieved from https://www.lonelyplanet.com/egypt/alexandria/attractions/bibliothecaalexandrina/a/poi-sig/1136427/355232

32. "Egypt builds a new capital city to replace Cairo". Retrieved from https://www.nbcnews.com/news/world/egypt-builds-new-capital-cityreplace-cairo-n893606

33. "Egypt to Become Home to the Tallest Tower in Africa". (2019). Retrieved from https://www.cairo360.com/article/sights-travel/egypt-tobecome-home-to-the-tallest-tower-in-africa/ 